\title{
KARAKTERISTIK MUTU FISIK TEKWAN KERING DENGAN RASIO IKAN BERBEDA
}

\section{[Physical Quality Characteristics of Dried Tekwan Made with Different Fish Ratio]}

\author{
Muhammad Irfan Febriansyah ${ }^{1)}$, Sukarno ${ }^{2) \star}$, dan Dedi Fardiaz ${ }^{2)}$ \\ 1) Program Studi IImu Pangan, Sekolah Pascasarjana, Institut Pertanian Bogor, Bogor \\ ${ }^{2)}$ Departemen Ilmu dan Teknologi Pangan, Fakultas Teknologi Pertanian, Institut Pertanian Bogor, Bogor
}

Diterima 4 Mei 2018 / Disetujui 28 Januari 2019

\begin{abstract}
Dried tekwan is a traditional restructured-fish product of South Sumatera processed by convectional drying. The study aimed to determine the effect of fish and tapioka ratio and tekwan's length on the physical quality of the dried tekwan. The physical quality of dried tekwan made with different ratio of fish and tapioca ratio (1:1, 1.5:1 and 2:1 (w:w)) and length 1,2, and $3 \mathrm{~cm}$ were investigated. The physical quality evaluated were the degree of whiteness, rehydration ratio, water holding capacity (WHC) and microstucture. The drying profile and proximate composition were also evaluated. There was no difference in the rate of drying of different fish:tapioca ratio as well a different tekwan length when free water evaporation was progressing. However, difference in drying rate was observed when the water content reached the equilibrium. Ratio 2:1 of fish and tapioca and $2 \mathrm{~cm}$ length of tekwan was found the to be best treatmentand resulting in dried tekwan with moisture content $10.22 \%$, ash $1.9 \%$, protein $27.9 \%$, fat $1.38 \%$, carbohydrate $58.6 \%$, whiteness $45.96 \%$ and expressible moisture content $2.06 \%$. Microstructure of dried tekwan with 2:1 ratio showed more compact structure and slight damage than 1.5:1 ratio. However, dried tekwan with 2:1 ratio still had lower rehydration properties than other treatment.
\end{abstract}

Keywords: dried tekwan, hot-air drying, microstructure, rehydration ratio, water holding capacity

\begin{abstract}
ABSTRAK
Tekwan kering merupakan salah satu produk restruktur ikan tradisional Sumatera Selatan yang telah dilakukan proses pengeringan. Penelitian ini bertujuan untuk menentukan pengaruh rasio ikan dan tapioka, serta ukuran potong (panjang) terhadap mutu fisik tekwan kering. Mutu fisik tekwan kering dengan rasio ikan dan tapioka (1:1, 1,5:1 dan 2:1 (b:b)) serta ukuran (panjang 1, 2 dan $3 \mathrm{~cm}$ ) telah dipelajari. Karakteristik mutu produk kering dianalisis dengan analisis derajat putih, rasio rehidrasi, water holding capacity (WHC) dan mikrostruktur. Profil pengeringan dan komposisi proksimat juga dievaluasi. Karakteristrik profil pengeringan pada setiap perlakuan rasio ikan dan tapioka serta ukuran potong tidak ditemukan perbedaan laju pengeringan ketika evaporasi air bebas berlangsung. Namun, perbedaan laju pengeringan ditemukan terjadi ketika kadar air memasuki kadar air equibrilium. Rasio ikan dan tapioka 2:1 dan ukuran potong $2 \mathrm{~cm}$ merupakan perlakuan terbaik dengan kadar air 10,22\%, abu 27,9\%, lemak $1,38 \%$, karbohidrat 58,6\%, derajat putih $45,96 \%$ dan kadar air terekspresi $2,06 \%$. Mikrostruktur tekwan kering dengan rasio 2:1 menunjukkan struktur yang kompak dan kerusakan struktur yang lebih sedikit dibandingkan dengan rasio 1,5:1. Namun, tekwan kering dengan ras io 2:1 memiliki karakteristik rehidrasi yang lebih rendah dibandingkan dengan perlakuan lain.
\end{abstract}

Kata kunci: kapasitas penahanan air (WHC), mikrostruktur, pengeringan udara panas, rasio rehidrasi, tekwan kering

\section{PENDAHULUAN}

Tekwan adalah salah satu produk tradisional restruktur ikan berasal dari Sumatera Selatan yang dikonsumsi dengan menggunakan kuah kaldu udang. Tekwan diproses melalui beberapa tahapan diantaranya penggilingan daging ikan, pencampuran bahan (ikan, tepung tapioka, air dan garam), pem-

*Penulis Korespondensi:

Email: dsukarno@apps.ipb.ac.id bentukan dan pemasakan dengan proses perebusan (Danar dan Dasir, 2017). Tekwan merupakan produk olahan ikan yang sama dengan pempek tetapi berbeda dalam penyajian. Tekwan memiliki kadar air yang tinggi yang berkisar antara $50-60 \%$ berat basah bahan. Kadar air yang tinggi ini dapat memicu terjadinya reaksi enzimatis dan aktivitas mikroba sehingga tekwan hanya dapat disimpan selama 2733 jam pada suhu kamar (Karneta et al., 2013). Salah satu upaya dalam meningkatkan stabilitas 
tekwan dalam penyimpanan adalah dengan pengeringan.

Pengeringan merupakan usaha dalam menurunkan kadar air dan aktivitas air $\left(\mathrm{a}_{\mathrm{w}}\right)$ dari dalam bahan. Penghilangan sebagian air dari dalam bahan menurunkan potensi kerusakan bahan selama penyimpanan pada suhu ruang akibat reaksi kimia dan aktivitas mikroba yang tidak diinginkan (Wang et al., 2011). Selain itu, beberapa produk kering memiliki tekstur dan rasa yang disukai oleh konsumen (Oliveira et al., 2016)

Secara tradisional, produsen lokal menggunakan metode pengeringan di bawah matahari terbuka untuk mengeringkan tekwan. Pengeringan di bawah matahari terbuka banyak digunakan di negara berkembang dengan iklim tropis dan sub tropis karena memiliki beberapa keunggulan diantaranya metode yang ekonomis, tidak memerlukan peralatan khusus dan konsumsi energi yang rendah (Komolafe et al., 2011). Namun, metode pengeringan matahari terbuka umumnya menghasilkan produk kering yang bermutu rendah dan heterogen. Beberapa faktor yang memengaruhi mutu produk pengeringan dengan metode matahari terbuka antara lain kondisi cuaca yang tidak dapat diduga, suhu pengeringan fluktuatif, kontaminasi mikroba, reaksi enzimatis serta lingkungan terpapar debu, serangga, hama dan kotoran burung (Wang et al., 2011). Davies dan Davies (2009) menambahkan bahwa kelemahan lain dari metode ini adalah laju pengeringan yang tidak terkontrol memungkinkan produk tidak cukup kering (under-drying) atau terlalu kering (over-drying). Produk under-drying memungkinkan kerusakan produk kering akibat cendawan sementara produk over-drying menyebabkan terjadinya pengerasan permukaan (case hardening).

Penggunaan metode pengering mekanis diperlukan untuk meningkatkan mutu produk kering. Salah satu metode pengeringan mekanis yang banyak digunakan untuk mengeringan produk pangan adalah pengeringan oven konvektif dengan udara panas. Pengeringan udara panas merupakan metode pengeringan dengan memaparkan bahan dengan laju aliran udara panas sebagai media agar air dapat terevaporasi dari bahan segar (Carrin dan Crapiste, 2009). Pengeringan dengan oven konvektif udara panas umumnya memiliki pengontrol laju kecepatan udara dan pengontrol panas yang menggunakan energi listrik. Sistem pengeringan tertutup dan terkontrol pada metode pengeringan oven konvektif udara panas menyebabkan difusifitas uap air yang lebih baik dibandingkan dengan pengeringan di bawah matahari terbuka (Fudholi et al., 2010). Selain itu, kontaminasi dari lingkungan selama proses pengeringan juga dapat dihindari. Faktor pengeringan yang terkontrol juga menyebabkan pengeringan hingga mencapai kadar air bahan yang diharapkan dapat ditentukan dan diprediksi (Erbay dan Icier, 2010).

Tekwan kering merupakan produk pangan olahan yang dikonsumsi dengan proses rehidrasi. Rehidrasi dan karakteristik fisik produk rehidrasi merupakan atribut mutu yang penting pada beberapa pangan kering. Penyerapan air selama rehidrasi merupakan proses yang kompleks yang dipengaruhi oleh beberapa faktor, diantaranya struktur morfologi, komposisi kimia, perlakuan pendahuluan pengeringan, metode pengeringan, media perendaman serta suhu dan waktu rehidrasi (Deng et al., 2014).

Struktur morfologi dan karakteristik kimia tekwan dipengaruhi oleh formulasi rasio ikan dan tapioka. Pembentukan tekstur oleh pati disebabkan oleh karakteristik granula pati yang mampu menyerap air selama pemanasan. Pati memiliki kemampuan penyerapan air yang dapat membantu meningkatkan kemampuan pengikatan air di dalam matrik pangan olahan (Zhang et al., 2013). Pati dalam pengeringan berperan penting dalam proses penyusutan, pembentukan porositas dan densitas kamba. Pengaruh pati dalam perubahan struktur fisik selama pengeringan dipengaruhi oleh rasio amilosa dan amilopektin. Pengeringan pati dengan rasio amilosa yang tinggi menghasilkan struktur berpori yang diakibatkan amilosa dengan rantai lurus mampu menyerap air lebih banyak dibandingkan amilopektin dengan rantai yang bercabang (Yadollahinia dan Jahangiri, 2009). Huda et al. (2010) menambahkan bahwa rasio ikan yang tinggi meningkatkan kekerasan dan meningkatkan kekompakan struktur serta menurunkan jumlah pori kerupuk ikan.

Penyusutan merupakan perubahan struktur fisik bahan selama proses pengeringan konvektif yang sulit dihindari. Di dalam pengeringan bahan segar dengan pori kapiler, porositas dipengaruhi oleh kadar air dan penyusutan bahan (Martynenko, 2008). Penyusutan terjadi akibat stress yang terjadi akibat panas pada struktur seluler memicu terjadi perubahan bentuk dan dimensi (Mayor dan Sereno, 2004). Tripathy dan Kumar (2009) melakukan pendekatan perlakuan bentuk geometri bahan agar dapat meminimalkan pengaruh penyusutan dan perubahan struktur akibat pengeringan terhadap produk rehidrasi.

Tekwan umumnya memiliki bentuk bulat kecil yang tidak seragam pada setiap sisinya. Arrieche et al. (2009) menyatakan pengeringan pada bahan berbentuk bulat memiliki gradien evaporasi kadar air permukaan lebih cepat dibandingkan bagian tengah sehingga bagian tengah bahan akan lebih terpengaruh oleh degradasi mekanis akibat transfer massa radial. Cunningham et al. (2008) juga menambahkan transfer masa pada produk silinder juga dipengaruhi oleh diameter silinder. Namun, menurut Ruiz-López et al. (2011) modifikasi pangan dengan bentuk hemispherical atau setengah bulat memiliki luas per- 
mukaan yang lebih besar dibandingan bentuk bulat, sehingga transfer massa hingga ke titik terdingin bahan lebih cepat berlangsung.

Penelitian mengenai produk tekwan kering atau produk sejenis seperti pempek kering telah dipelajari oleh Danar dan Dasir (2017). Namun, tekwan dan pempek kering yang dihasilkan masih memerlukan waktu rehidrasi yang lama yaitu 6 jam dan laju absorpsi air 4,09\% air/60 menit, serta penerimaan panelis yang kurang disukai. Oleh karena itu, pengaruh rasio ikan dan tapioka serta ukuran potong dengan dimensi geometri hemi-silinder sebagai faktor dimensi terhadap perubahan mutu fisik tekwan kering perlu dikaji dalam penelitian ini.

\section{BAHAN DAN METODE}

\section{Bahan}

Bahan yang digunakan dalam penelitian ini antara lain lkan tenggiri yang diperoleh dari pasar tradisional Bogor, tapioka (PT. Budi Starch \& Sweetener, Lampung, Indonesia), dan garam $\mathrm{NaCl}$ (Unichem Candi Indonesia, Gresik, Indonesia).

\section{Preparasi Sampel}

Formulasi tekwan dilakukan berdasarkan metode Karneta et al. (2013) dengan modifikasi rasio ikan:tapioka, dimensi dengan mencetak menggunakan selongsong sosis dan kontrol suhu pengukusan $\left(65^{\circ} \mathrm{C}\right)$. Ikan tenggiri dibersihkan dari kepala, isi perut, tulang, kepala dan kulit. Daging ikan tenggiri kemudian dicuci dan dipisahkan dari daging merah, kemudian daging digiling menggunakan meat grinder. Daging ikan tenggiri giling dan tepung tapioka dicampurkan sesuai dengan formulasi hingga bahan menjadi homogen (Tabel 1).

Tabel 1. Formulasi bahan dalam pembuatan tekwan

\begin{tabular}{lccc}
\hline \multirow{2}{*}{ Bahan } & \multicolumn{3}{c}{ Jumlah Bahan (gram) } \\
\cline { 2 - 4 } & $\begin{array}{c}\text { Formulasi 1 } \\
(1: 1)\end{array}$ & $\begin{array}{c}\text { Formulasi 2 } \\
(1,5: 1)\end{array}$ & $\begin{array}{c}\text { Formulasi 3 } \\
(2: 1)\end{array}$ \\
\hline Ikan & 500 & 600 & 667 \\
Tapioka & 500 & 400 & 333 \\
\hline Total & 1000 & 1000 & 1000 \\
\hline
\end{tabular}

Garam $(\mathrm{NaCl})$ sebanyak 2,5\% dari total berat ikan dan tepung pada adonan dilarutkan dalam air es kemudian ditambahkan pada adonan. Jumlah air yang digunakan mengikuti rumus: 95\% total berat ikan dan tepung-(kadar air ikan $\mathrm{x}$ berat ikan)-(kadar air tepung $x$ berat tepung) (Karneta et al., 2013). Selanjutnya, tekwan dibentuk silinder menggunakan selongsong sosis dengan diameter $17 \mathrm{~mm}$. Selanjutnya, tekwan silinder dikukus pada suhu $65^{\circ} \mathrm{C}$ selama 20 menit menggunakan steamer. Tekwan berbentuk silinder dibuat menjadi 3 ukuran potong (panjang), antara lain 1, 2 dan $3 \mathrm{~cm}$. Tekwan silinder yang telah dipotong sesuai ukuran potong kemudian dipotong menjadi dua tepat ditengah diameter silinder tekwan dengan ketebalan $1 \mathrm{~cm}$ sehingga tekwan berbentuk hemi-silinder. Ukuran dimensi tekwan dikonfirmasi menggunakan jangka sorong. Tekwan disimpan pada suhu $4^{\circ} \mathrm{C}$ maksimal 2 hari sebelum dikeringkan.

\section{Metode pengeringan (Djendoubi et al., 2009)}

Oven pengering (tipe AM-TD12, Newland Engineering, Yogyakarta, Indonesia) tipe kabinet dengan udara panas yang memiliki 14 rak bahan digunakan dalam penelitian ini. Oven pengering dioperasikan pada suhu $70^{\circ} \mathrm{C}$ dengan kecepatan udara $1 \mathrm{~m} / \mathrm{s}$. Pengeringan dilakukan selama 7 jam dan sampel tekwan akan dianalisa kadar air tanpa mengembalikan sampel tersebut selama selang waktu 30 menit.

\section{Profil pengeringan (Roberts et al., 2008)}

Profil pengeringan diamati dengan menggunakan persamaan laju pengeringan $\left(\mathrm{N}_{\mathrm{w}}\right)=\left(\mathrm{M}_{\mathrm{t}+\mathrm{dt}}-\mathrm{M}_{\mathrm{t}}\right) / \mathrm{dt}$ dan persamaan moisture ratio $(\mathrm{MR})=\left(\mathrm{M}_{\mathrm{t}}-\mathrm{M}_{\mathrm{e}}\right) /\left(\mathrm{M}_{0}-\right.$ $M_{e}$ ) dimana Nilai $M_{0}, M_{t}, M_{e}$, dan $M_{t+d t}$ berturut-turut merupakan kadar air awal, kadar air pada waktu ke$t$, kadar air kesetimbangan dan kadar air pada $t+d t$ (kg air/kg bahan kering), serta $t$ adalah waktu pengeringan dalam menit. Kadar air bahan dinyatakan sebagai kadar air basis kering ( $\mathrm{kg}$ air/kg bahan kering). Nilai kadar air kesetimbangan $\left(M_{e}\right)$ ditentukan dengan memperpanjang waktu pengeringan hingga tidak terjadi perbedaan berat pada bahan pada suhu yang berbeda.

\section{Analisis proksimat}

Analisis kadar air, kadar abu, kadar protein, kadar lemak dan karbohidrat (by difference) dikerjakan menggunakan metode AOAC (2012).

\section{Derajat putih (Sikes et al., 2009)}

Sampel kering dan sebelum dikeringkan dianalisis menggunakan chromameter (tipe CR 200, Minolta Corp, Osaka, Jepang) yang telah dikalibrasi dengan kartu berwarna putih. Nilai warna dinyatakan dengan skala warna $\mathrm{CIE}$, antara lain $L^{*}$ (kecerahan/kegelapan), $a^{*}$ (kemerahan/kehijauan) dan $b^{*}$ (kekuningan/kebiruan). Koordinat kromatis $L^{*}, a^{*}$ dan $b^{*}$ dikonversi menjadi nilai whiteness dengan menggunakan rumus:

$$
\begin{aligned}
& \text { Derajat putih (Whiteness) } \\
& \qquad=100-\left[(100-L)^{2}+a^{2}+b^{2}\right]^{1 / 2}
\end{aligned}
$$

Rasio rehidrasi (Deng et al., 2014)

Sampel tekwan kering direhidrasi dalam air distilasi pada suhu $60^{\circ} \mathrm{C}$ dengan perbandingan sampel dan air 1:50 (b:v) selama 15 menit. Sampel diangkat dan air dipermukaan sampel hisap dengan tisu dan ditimbang. Proses rehidrasi dilakukan hingga diper- 
oleh berat sampel diantara dua pengukuran tidak signifikan. Berat yang diperoleh selama rehidrasi dihitung menggunakan rumus sebagai berikut: WGR = $\left(\mathrm{W}_{\mathrm{t}}-\mathrm{W}_{\mathrm{d}}\right) / \mathrm{W}_{\mathrm{d}} \times 100$. Variabel WGR, Wt, dan $\mathrm{Wd}$ secara berturut-turut merupakan rasio penambahan berat selama rehidrasi $(\mathrm{g})$, berat sampel setelah direhidasi pada waktu ke-t (g) dan berat sampel sebelum rehidrasi $(\mathrm{g})$.

Kurva rehidrasi tekwan kering dinyatakan sebagai persen penambahan berat selama rehidrasi (WGR) ditampilkan pada Gambar 3 Regresi linier dan regresi linier tersegmentasi atau regresi piecewise dengan kepercayaan model regresi $95 \%$ digunakan dalam kurva rehidrasi.

Water holding capacity (WHC), metode gravime-
teri (lee dan Patel, 1984)
$\quad$ Water holding capacity dinyatakan sebagai expressible moisture atau air yang keluar dari sistem pangan akibat pemberian tekanan dari luar. Analisis WHC dilakukan menggunakan metode kompresi menggunakan instrumen Hardness Tester (tipe 174 886, Kiya Seisakusho. Ltd, Tokyo, Jepang). Sampel tekwan dan kertas saring dengan diameter $12,5 \mathrm{~cm}$ ditimbang berat awal hingga ketelitian 0,001 g. Analisis dilakukan dengan meletakkan 2 lembar kertas saring pada bagian bawah sampel dan 2 lembar kertas saring diletakkan pada bagian atas sampel. Pengujian kompresi dilakukan dengan beban kompresi $2 \mathrm{~kg}$ selama 5 menit. Selanjutnya, kertas saring ditimbang berat akhirnya. Expressible moisture Content (EMC) dinyatakan dengan rumus: EMC (\%) = (berat awal-berat akhir)/berat awalx100. Persentase expressible moisture yang tinggi menunjukkan WHC yang rendah.

Analisis mikrostruktur, metode scanning electron Microscopy (Sun et al., 2014)

Sampel tekwan segar (kontrol) dikeringkan menggunakan freeze drying selama 72 jam. Sampel tekwan kering dan kontrol dipotong tipis pada bagian radial sisi bagian dalam bahan. Ketebalan potong 1 $\mathrm{mm}$ dan ditempatkan pada lempeng analisa SEM (tipe EVO MA 10, Carl Zeiss, Inggris) yang kemudian dilapisi dengan emas untuk memberikan permukaan reflektif untuk pancaran elektron. Pelapisan emas dilakukan pada sputter coater dibawah tekanan vakum rendah dengan gas inert. Sampel berlapis emas kemudian diamati dibawah mikroskop.

\section{Analisis data}

Rancangan perlakuan yang digunakan dalam penelitian ini adalah rancangan acak kelompok faktorial (RAKF) dengan menggunakan software Rstudio (ver 1.1.456, Boston, Amerika Serikat). Pembahasan dilakukan secara deskriptif dan ANOVA (Analysis of Variance) serta dilanjutkan dengan uji lanjut
DMRT (Duncan's Multiple Range Test) (Mattjik dan Sumertajaya, 2013)

\section{HASIL DAN PEMBAHASAN}

\section{Profil penurunan kadar air dan laju pengeringan}

Proses pengeringan tekwan dengan perlakuan rasio ikan:tapioka dilakukan dengan kadar air awal berkisar antara 58,74-68,85\%bb. Kadar air tekwan segar dan kering ditampilkan pada Tabel 2. Kadar air akhir tekwan kering berkisar antara 10,08$17,85 \%$ bb dengan kadar air tekwan kering tertinggi terdapat pada rasio $2: 1$ (b:b) dan ukuran potong 3 $\mathrm{cm}$ sedangkan kadar air terendah terdapat pada tekwan kering dengan rasio 1:1 (b:b) dan ukuran potong $1 \mathrm{~cm}$.

Tabel 2. Profil perubahan kadar air tekwan kering dengan rasio ikan dan rapioka serta ukuran potong (panjang) yang berbeda.

\begin{tabular}{|c|c|c|c|}
\hline \multirow{2}{*}{$\begin{array}{c}\text { Rasio Tekwan } \\
\text { (ikan:Tapioka) } \\
\text { (b:b) }\end{array}$} & \multirow{2}{*}{$\begin{array}{c}\text { Ukuran } \\
\text { Potong } \\
\text { (cm) }\end{array}$} & \multicolumn{2}{|c|}{ Kadar Air (\%bb) } \\
\hline & & Awal & Akhir \\
\hline \multirow{3}{*}{ Rasio 1:1 } & 1 & & $10,08 \pm 0,004^{u}$ \\
\hline & 2 & $58,73 \pm 1,38^{C}$ & $12,80 \pm 0,01^{\mathrm{c}}$ \\
\hline & 3 & & $12,86 \pm 0,01^{\iota}$ \\
\hline \multirow{3}{*}{ Rasio $1,5: 1$} & 1 & & $11,87 \pm 0,01^{\mathrm{c}}$ \\
\hline & 2 & $68,84 \pm 1,76^{\mathrm{A}}$ & $16,06 \pm 0,01^{a v}$ \\
\hline & 3 & & $17,85 \pm 0,02^{a}$ \\
\hline \multirow{3}{*}{ Rasio 2:1 } & 1 & & $13,13 \pm 0,003^{\mathrm{C}}$ \\
\hline & 2 & $62,70 \pm 1,59^{\mathrm{B}}$ & $15,67 \pm 0,01^{\nu}$ \\
\hline & 3 & & $16,69 \pm 0,02^{a w}$ \\
\hline
\end{tabular}

Keterangan: notasi huruf yang berbeda pada kolom menunjukkan perbedaan nyata antar perlakuan $(P \leq 0,05)$

Kurva penurunakan kadar air ditampilkan dengan konversi kadar air menjadi rasio kadar air yang tidak berdimensi (Gambar 1). Gambar 1 (A-C) menunjukkan proses pengeringan terjadi selama periode laju penurunan. Profil pengeringan tekwan pada ketiga rasio ikan dan tapioka menunjukkan adanya 2 periode laju penurunan. Profil pengeringan dengan 2 periode laju penurunan telah dilaporkan pada beberapa pangan segar seperti ikan (Reza et al., 2009; Mustapha et al., 2014), apel (Seiiedlou et al., 2010), dan rumput laut (Gupta et al., 2011).

Gambar 1 juga menampilkan pengaruh ukuran potong terhadap profil penurunan kadar air selama pengeringan. Ukuran potong yang lebih kecil memiliki profil penurunan kadar air lebih cepat. Sementara, rasio ikan dan tapioka tidak menunjukkan perbedaan penurunan kadar air yang signifikan.

Gambar 2 (A-C) menunjukkan laju pengeringan tidak berlangsung konstan. Laju pengeringan terjadi 
dalam 2 periode. Periode pertama (1) laju pengeringan pada tekwan kering dengan setiap perlakuan memiliki kemiringan yang tajam, sementara laju pengeringan periode kedua (2) memiliki kecenderungan evaporasi yang konstan.
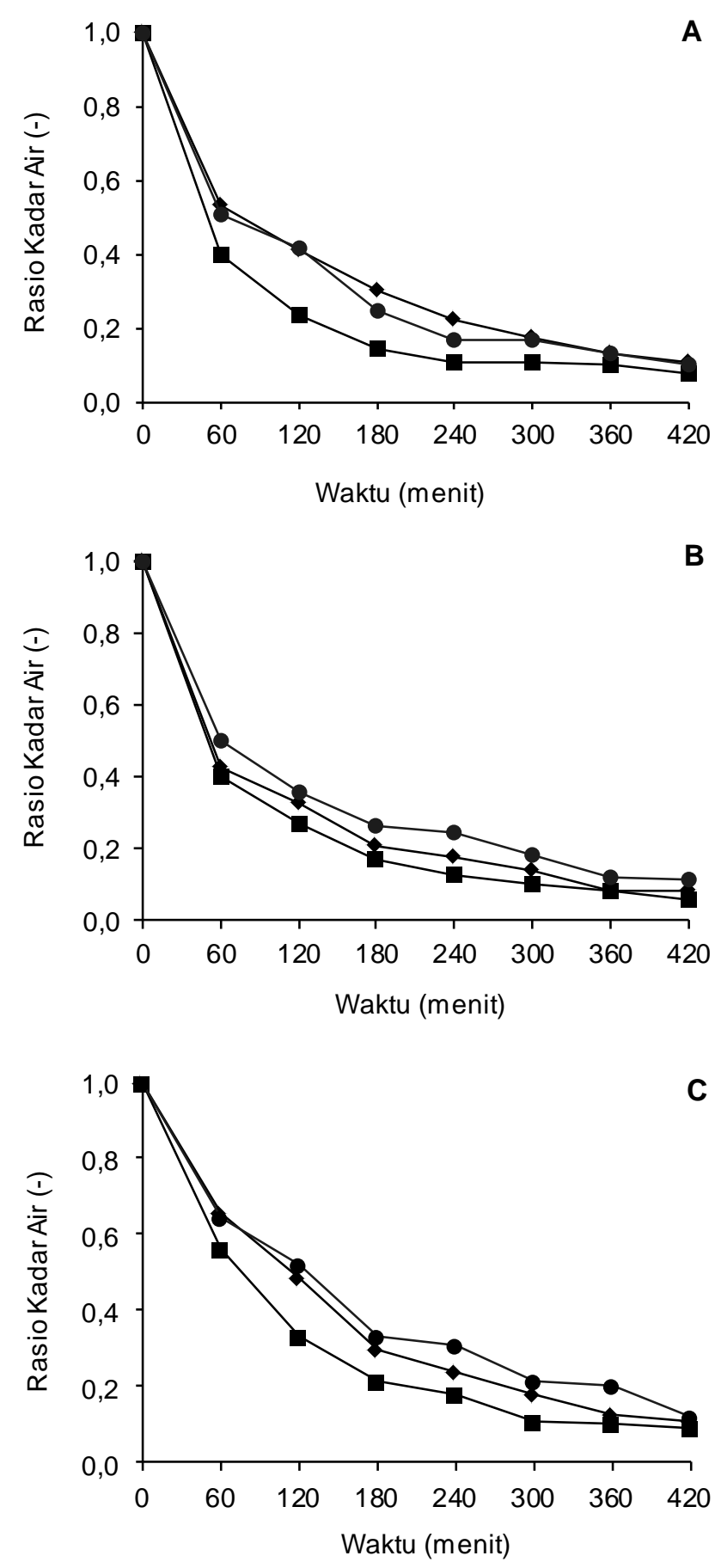

Gambar 1. Kurva pengeringan tekwan (ikan:tapio$\mathrm{ka}):(\mathrm{A})$ rasio $1: 1$, (B) rasio $1,5: 1$, dan (C) rasio 2:1 dengan ukuran potong 1 $\mathrm{cm}(\bullet), 2 \mathrm{~cm}(\bullet)$ dan $3 \mathrm{~cm}(\bullet)$
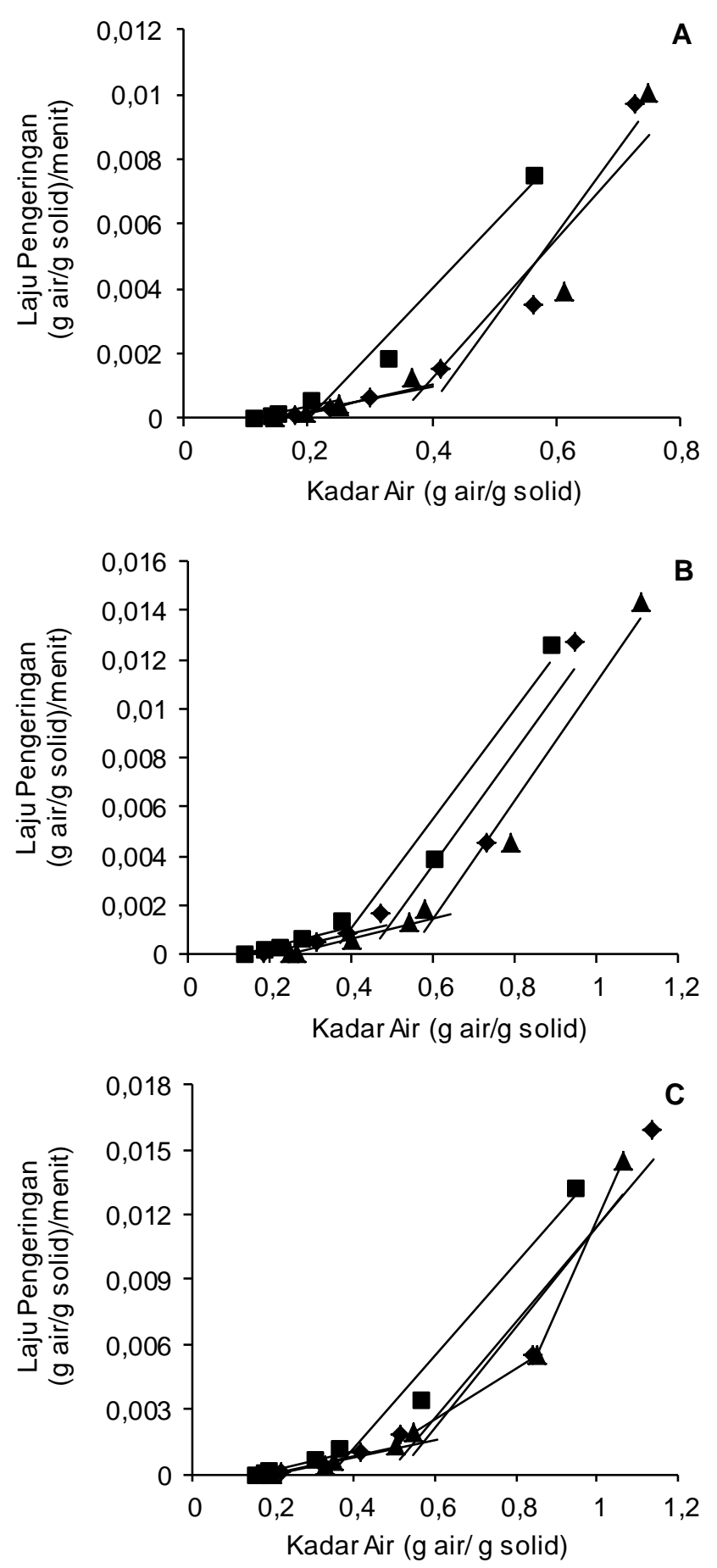

Gambar 2. Laju pengeringan tekwan (ikan:tapioka): (A) rasio $1: 1$, (B) rasio $1,5: 1$, dan (C) rasio 2:1 dengan ukuran potong 1 $\mathrm{cm}(\bullet), 2 \mathrm{~cm}(\bullet)$ dan $3 \mathrm{~cm}(\bullet)$ dalam dua [(1) dan (2)] periode dehidrasi

Laju pengeringan periode pertama ini menunjukkan terjadinya evaporasi uap air bebas atau air terikat tipe III. Setelah uap air bebas mulai jenuh, evaporasi air terikat sekunder (tipe II) dan tersier (tipe I) berlangsung hingga fase equivalen. 
Slope laju pengeringan ditampilkan pada Tabel 3. Laju pengeringan periode pertama menunjukkan tidak terdapat perbedaan yang signifikan, sementara laju pengeringan kedua terdapat perbedaan signifikan antara rasio ikan dan tapioka $(P<0,05)$. Penurunan kecepatan laju penurunan periode kedua terjadi linier dengan meningkatnya rasio ikan. Hal ini menunjukkan bahwa pengecilan ukuran potong (panjang) pada sampel menurunkan resistensi eksternal akibat luas permukaan yang berinteraksi dengan uap panas lebih besar sementara rasio ikan dan tapioka memengaruhi resistensi internal dalam proses evaporasi air. Brasiello et al. (2013) menyatakan bahwa pati memberikan struktur yang berpori pada produk kering akibat terlepasnya air yang tertahan didalam struktur. Hasil yang sama juga dilaporkan (Wang et al., 2013) pada produk restruktur ikan. Struktur yang berpori ini diduga menjadi faktor utama yang memengaruhi penurunan resistensi internal evaporasi uap air didalam penelitian ini.

Tabel 3. Laju pengeringan tekwan kering pada dua periode laju yang berbeda

\begin{tabular}{ccc}
\hline \multirow{2}{*}{$\begin{array}{c}\text { Rasio Tekwan } \\
\text { (Ikan:Tapioka) }(\mathrm{b}: \mathrm{b})\end{array}$} & \multicolumn{2}{c}{ Slope Periode Laju Pengeringan } \\
\cline { 2 - 3 } & $(1)$ & $(2)$ \\
\hline $1: 1$ & $0,0228 \pm 0,0040^{\mu}$ & $0,0038 \pm 0,0004^{\mathrm{D}}$ \\
$1,5: 1$ & $0,0240 \pm 0,0027^{\mu}$ & $0,0041 \pm 0,0001^{\text {a }}$ \\
$2: 1$ & $0,0218 \pm 0,0015^{\mu}$ & $0,0042 \pm 0,0002^{\mathrm{a}}$
\end{tabular}

Keterangan: Notasi hurufyang berbeda menunjukkan perbedaan nyata antar perlakuan $(P \leq 0,05)$

\section{Karakteristik kimia}

Komposisi proksimat tekwan kering ditampilkan pada Tabel 4. Perbedaan signifikan $(P<0,05)$ terdapat pada komposisi proksimat tekwan kering kecuali kadar lemak. Peningkatan rasio ikan didalam formulasi tekwan kering meningkatkan nilai kadar air, abu dan protein. Nurnadia et al. (2011) menyatakan bahwa ikan tenggiri (Scromberomorus guttatus) merupakan ikan pelagis yang memiliki kadar air $82,12 \%$, abu $1,24 \%$, protein $19,77 \%$ dan lemak $1,05 \%$.

Kadar air akhir tekwan lebih tinggi diperoleh dengan meningkatnya rasio ikan. Kadar air tekwan kering pada penelitian ini diperoleh lebih rendah dibandingkan kadar air tekwan kering dengan pengeringan tradisional yaitu 11\%bb (Agustini et al., 2009), tetapi lebih tinggi dibandingkan dengan tekwan kering dengan pengeringan dua tahap dengan suhu yang berbeda (40 dan $50^{\circ} \mathrm{C}$ ), yaitu 5,7\%bb (Danar dan Dasir, 2017). Perbedaan kadar air diduga disebabkan oleh perbedaan laju transfer massa pada setiap metode pengeringan dan lama pengeringan. VegaGálvez et al. (2009) menyatakan peningkatan suhu pengeringan meningkatkan difusivitas termal bahan. Namun, suhu yang lebih tinggi dan waktu pengeringan yang panjang memungkinkan terjadinya penge- rasan permukaan bahan sehingga pergerakan air didalam bahan menjadi terhambat meskipun kurva pengeringan (Gambar 1) menunjukkan telah tercapainya fase penurunan konstan (Gulati dan Datta, 2015).

Tabel 4. Analisis proksimat tekwan kering dengan rasio ikan dan tapioka yang berbeda

\begin{tabular}{cccccc}
\hline \multirow{2}{*}{ Perlakuan } & $\begin{array}{c}\text { Kadar } \\
\text { air } \\
(\% \mathrm{bb})\end{array}$ & $\begin{array}{c}\text { Abu } \\
(\% \mathrm{bb})\end{array}$ & $\begin{array}{c}\text { Protein } \\
(\% \mathrm{bb})\end{array}$ & $\begin{array}{c}\text { Lemak } \\
(\% \mathrm{bb})\end{array}$ & $\begin{array}{c}\text { Karbohidrat } \\
(\% \mathrm{bb})^{*}\end{array}$ \\
\hline $1: 1$ & $7,84 \pm$ & $0,69 \pm$ & $14,20 \pm$ & $1,89 \pm$ & $75,38 \pm$ \\
& $2,50^{\mathrm{c}}$ & $0,05^{\mathrm{b}}$ & $2,98^{\mathrm{b}}$ & 0,48 & $3,46^{\mathrm{a}}$ \\
$1,5: 1$ & $9,33 \pm$ & $0,69 \pm$ & $14,93 \pm$ & $1,62 \pm$ & $73,43 \pm$ \\
& $2,85^{\mathrm{b}}$ & $0,19^{\mathrm{b}}$ & $2,97^{\mathrm{b}}$ & 0,24 & $2,89^{\mathrm{b}}$ \\
$2: 1$ & $10,22 \pm$ & $1,9 \pm$ & $27,90 \pm$ & $1,38 \pm$ & $58,60 \pm$ \\
& $3,19^{\mathrm{a}}$ & $0,51^{\mathrm{a}}$ & $6,36^{\mathrm{a}}$ & 0,59 & $4,34^{\mathrm{c}}$ \\
\hline
\end{tabular}

Keterangan: Notasi huruf yang berbeda menunjukkan perbedaan nyata antar perlakuan $(P \leq 0,05) .{ }^{*}$ karbohidrat dihitung berdasarkan by different

Tabel 4 turut menunjukkan rasio ikan yang lebih tinggi meningkatkan kadar protein dan menurunkan kadar karbohidrat tekwan kering. Ikan diketahui secara umum merupakan sumber protein yang sangat baik sedangkan tapioka memiliki kadar protein yang rendah yaitu berkisar 0,7-1,18\% (Breuninger et al., 2009).

\section{Karakteristik rehidrasi}

Karakteristik rehidrasi produk kering dapat menjadi indikasi perubahan mutu fisik dan kimia akibat pengeringan. Karakteristik tersebut dipengaruhi oleh metode pengeringan, suhu pengeringan, bentuk, ukuran dan komposisi bahan (Tripathy dan Kumar, 2009). Waktu rehidrasi selama perendaman dengan air merupakan karakteristik rehidrasi tekwan kering yang diharapkan. Kurva rehidrasi tekwan kering dengan rasio ikan:tapioka (1:1, 1,5:1 dan 2:1 (b:b)) dan ukuran potong $(1,2$ dan $3 \mathrm{~cm})$ berbeda ditampilkan pada Gambar 3. Rehidrasi tekwan kering menunjukkan terjadinya penambahan berat tekwan rehidrasi seiring dengan lama waktu rehidrasi hingga mencapai fase stabil. Laju penambahan berat rehidrasi tekwan berlangsung dengan cepat pada periode awal rehidrasi dan melambat pada periode berikutnya. Periode awal rehidrasi yang berlangsung dengan cepat berkaitan dengan fenomena kapilaritas dan daerah dekat permukaan bahan yang terisi dengan cepat. Sebagai hasil penyerapan air, tingkat rehidrasi menurun akibat laju ekstraksi yang meningkat dari bahan terlarut dan pengisian ruang kapiler dan interselluler dengan air (Cunningham et al., 2008). Karakteristik rehidrasi yang sama telah dipelajari oleh Deng et al. (2014) pada fillet cumi-cumi. 

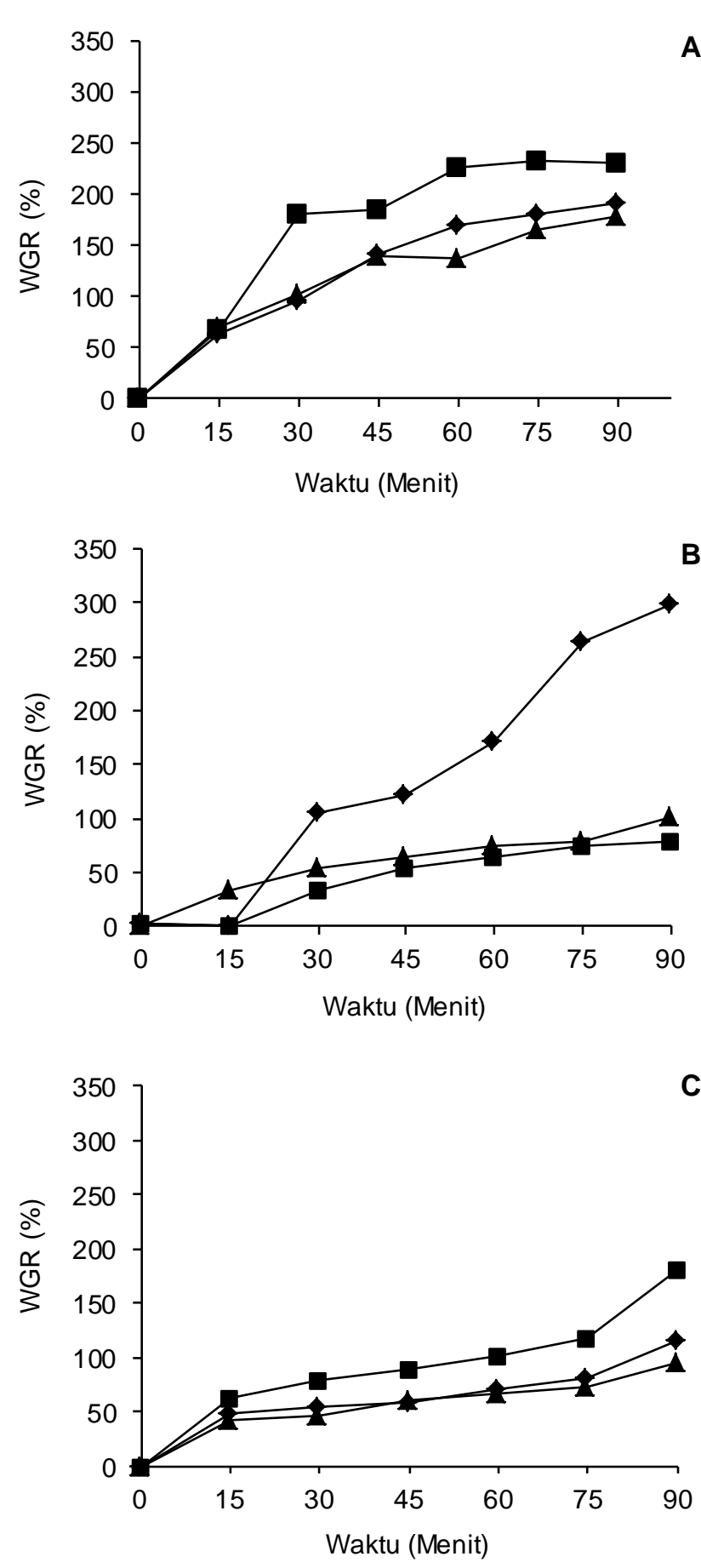

Gambar 3. Kurva rehidrasi tekwan kering (ikan: tapioka): (A) rasio 1:1, (B) rasio 1,5:1, dan $(\mathrm{C})$ rasio 2:1 dengan ukuran potong $1 \mathrm{~cm} \mathrm{( \bullet ),} 2 \mathrm{~cm}(\bullet)$ dan $3 \mathrm{~cm} \mathrm{( \Delta )}$

Gambar 3 (a-c) menunjukkan rasio ikan:tapioka dan ukuran potong memengaruhi profil rehidrasi tekwan kering. Peningkatan rasio ikan menunjukan terjadinya penurunan laju rehidrasi tekwan kering. Fase stabil rasio rehidrasi relatif tekwan kering pada rasio 1:1, 1,5:1 dan 2:1 (b:b) tercapai secara bertu- rut-turut, antara lain: 30, 45 dan 75 menit. Konsentrasi tapioka berbeda diduga menjadi faktor utama yang memengaruhi rasio rehidrasi tekwan kering. Evaporasi uap air dalam jaringan pati dan tapioka selama pengeringan meninggalkan pori atau rongga kosong (Aprajeeta et al., 2015). Rongga kosong tersebut terisi dengan cepat selama proses rehidrasi sehing-ga tekwan dengan rasio ikan lebih sedikit memiliki karakteristik rehidrasi yang lebih cepat. Namun, tek-wan dengan jumlah tapioka yang lebih tinggi berpo-tensi terjadinya cooking loss atau leaching selama proses rehidrasi (Wang et al., 2013).

Gambar 3 juga menunjukkan terjadinya peningkatan WGR setelah mencapai WGR $100 \%$. Peningkatan WGR tersebut diduga disebabkan oleh telah tercapainya kapasitas rehidrasi bahan sehingga bahan tidak mampu menahan air di dalam jaringan. Proses rehidrasi lebih lanjut tersebut menyebabkan terjadinya leaching dan terjadinya retakan pada struktur fisik tekwan rehidrasi. Proses leaching atau cooking loss terjadi pada setiap perlakuan rasio ikan dan tapioka tetapi rasio ikan yang lebih tinggi menunjukkan kecenderungan lebih resisten terhadap leaching. Hal ini diduga disebabkan oleh protein ikan membantu dalam meningkatkan kapasitas rehidrasi bahan. Selain itu, reaksi Maillard yang terjadi selama pengeringan membentuk struktur kompleks yang menyebabkan struktur bahan lebih kompak (Zhou et al., 2013).

Gambar 3 turut menampilkan faktor perlakuan ukuran potong terhadap karakteristik rehidrasi. Peningkatan ukuran potong (panjang) menunjukkan terjadinya penurunan rasio rehidrasi. Hal ini berhubungan dengan luas permukaan yang berinteraksi dengan air. Cunningham et al. (2008) menambahkan bahwa dimensi panjang pada karakteristik rehidrasi memengaruhi kapasitas rehidrasi bahan kering sementara dimensi radial memengaruhi transfer massa.

Rehidrasi memiliki tiga proses utama yang simultan diantaranya imbibisi air kedalam bahan kering, pembengkakaan bahan dan leaching padatan terlarut (Maldonado et al., 2010). Rehidrasi menyebabkan pembengkakan bahan hingga batas tertentu. Kapasitas rehidrasi bahan berperan dalam batas pembengkakan bahan. Rehidrasi bahan yang melebihi batas kapasitas rehidrasi menyebabkan terjadinya cooking loss atau leaching (Wang et al., 2013).

\section{Water holding capacity}

Water holding capacity (WHC) didefinisikan sebagai kemampuan produk pangan untuk menahan air yang ada di dalam strukturnya dari pemberian gaya dari luar seperti proses pemotongan atau penekanan (Tee dan Siow, 2014). WHC tekwan kering yang telah direhidrasi dinyatakan sebagai expressible moisture content (EMC) atau air yang terekspre- 
si akibat pemberian tekanan. EMC merupakan indikator peningkatan mobilitas air didalam sistem pangan (Arimi et al., 2010). Semakin tinggi nilai EMC maka semakin rendah WHC sampel tekwan. Hasil analisis EMC tekwan rehidrasi ditampilkan pada Tabel 5 .

Tabel 5. Expresible moisture content (EMC) tekwan rehidrasi dengan faktor rasio ikan dan tapioka serta ukuran potong (panjang)

\begin{tabular}{ccccc}
\hline & \multicolumn{3}{c}{$\begin{array}{c}\text { Expressible Moisture Content } \\
\text { Tekwan }\end{array}$} & $\begin{array}{c}\text { Rerata } \\
\text { Rasio } \\
\text { (lkan:Tapioka) }\end{array}$ \\
\cline { 2 - 4 } & \multicolumn{3}{c}{ Ukuran (cm) } & \\
\cline { 2 - 4 } & 1 & 2 & 3 & \\
\cline { 2 - 4 } $1: 1$ & $24,59 \pm$ & $18,28 \pm$ & $15,48 \pm$ & $9,46 \pm$ \\
& $2,80^{\mathrm{a}}$ & $6,10^{\mathrm{b}}$ & $1,85^{\mathrm{b}}$ & $5,33^{\mathrm{a}}$ \\
$1.5: 1$ & $17,19 \pm$ & $13,71 \pm$ & $3,22 \pm$ & $11,37 \pm$ \\
& $1,92^{\mathrm{b}}$ & $3,20^{\mathrm{b}}$ & $0,67^{\mathrm{C}}$ & $6,58^{\mathrm{b}}$ \\
$2: 1$ & $6,12 \pm$ & $2,06 \pm$ & $2,61 \pm$ & $3,60 \pm$ \\
& $0,89^{\mathrm{c}}$ & $0,20^{\mathrm{C}}$ & $0,29^{\mathrm{c}}$ & $1,97^{\mathrm{c}}$ \\
\hline Rerata & $15,97 \pm$ & $11,35 \pm$ & $7,11 \pm$ \\
Ukuran & $8,24^{\mathrm{A}}$ & $8,02^{\mathrm{B}}$ & $6,37^{\mathrm{C}}$ & \\
\hline
\end{tabular}

Keterangan: Notasi huruf yang berbeda menunjukkan perbedaan nyata antar perlakuan $P \leq 0,05$ )

Analisis statistik EMC menghasilkan terdapat perbedaan nyata $(P<0,05)$ baik interaksi perlakuan (rasio ikan dan tapioka serta ukuran potong) maupun pada masing-masing perlakuan. Tabel 5 menunjukkan adanya kecenderungan penurunan signifikan EMC $(P<0,05)$ terhadap peningkatan rasio ikan menurunkan nilai EMC tekwan rehidrasi.

Protein myofibril dan aktomiosin pada ikan memiliki kemampuan pembentukan gel yang baik dengan interaksi protein dan air. Proses denaturasi oleh paparan panas menyebabkan terjadinya perubahan hidrofobisitas permukaan protein dan memungkinkan terbentuknya ikatan cross-link kovalen (Ramírez et al., 2011). Pada produk segar, kemampuan retensi air ke dalam protein denaturasi memengaruhi WHC dari struktur gel protein (Wang et al., 2013). Namun pada produk rehidrasi, perubahan struktur dapat terjadi selama proses pengeringan. Perubahan struktur fisik seperti penyusutan sulit dihindari pada pengeringan menggunakan metode konvektif udara panas. WHC pada tekwan kering diduga dipengaruhi oleh struktur penyusutan protein fibril, ikatan cross-link kovalen antar agregat protein, dan ikatan disulfida intermolekul. Zhou et al. (2013) menyatakan bahwa pembentukan ikatan intermolekul protein dan pati termediasi melalui reaksi Maillard.

Menurut Ramírez et al. (2011), penambahan tapioka dalam konsentrasi rendah mampu meningkatkan karakteristik mekanis gel protein dengan membentuk kompleks protein dan pati. Pati di dalam pembentukan gel protein tersebut berperan dalam membantu pembentukan gel akibat protein terdenaturasi parsial oleh lemak ikan yang teroksidasi. Namun di dalam penelitian ini, peningkatan jumlah rasio tapioka meningkatkan secara signifikan $(P<0,05)$ nilai EMC tekwan (Tabel 5). Hal ini diduga matriks gel tapioka terjadi penyusutan dengan cepat selama pengeringan akibat resistensi internal yang rendah sehingga meninggalkan pori pada struktur matriks tekwan (Ramadhan et al., 2014). Joardder et al. (2016) menambahkan bahwa pembentukan pori pada produk kering dipengaruhi oleh beberapa faktor, diantaranya kadar air, struktur produk segar, ukuran, tipe pengeringan, komposisi, bentuk, kecepatan udara, $\mathrm{RH}$, tekanan dan suhu. Pembentukan pori di dalam struktur ini menyebabkan meningkatnya air yang terekspresi yang disebabkan oleh struktur pangan tidak memiliki resistensi terhadap penahanan air (Wang et al., 2013).

Peningkatan ukuran juga menunjukkan kecenderungan penurunan signifikan $(P<0,05)$ nilai EMC (Tabel 5). Pengecilan ukuran potong menyebabkan luas permukaan yang berinteraksi dengan udara panas semakin besar sehingga pelepasan kadar air semakin cepat (Gambar 1). Joardder et al. (2016) menyatakan laju pengeringan yang cepat ini meningkatkan potensi terbentuknya pori lebih tinggi.

\section{Derajat putih}

Warna tekwan kering merupakan salah satu parameter yang relevan dalam penentuan mutu produk. Analisis pengaruh perlakuan penelitian (rasio ikan dan tapioka, serta ukura potong) dalam pengeringan konvektif terhadap perubahan warna tekwan

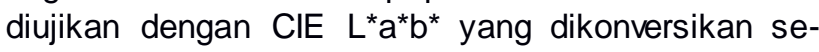
bagai perubahan derajat putih (whiteness). Hasil analisis derajat putih ditampilkan pada Gambar 4.

Gambar 4 menunjukkan perlakuan pengeringan penurunan signifikan $(P<0,05)$ derajat putih tekwan. Tekwan kering dengan rasio 1:1 (b:b) memiliki warna yang lebih putih dibandingkan dengan perlakuan lain. Sementara dibandingkan dengan rasio lain, tekwan dengan rasio 1.5:1 (b:b) memiliki warna yang lebih gelap. Penurunan derajat putih diduga terjadi diakibatkan dengan proses pengeringan dengan suhu yang tinggi $\left(70^{\circ} \mathrm{C}\right)$ pada bahan dengan karakteristik tinggi protein dan karbohidrat memicu terjadinya reaksi Maillard selama proses termal berlangsung. Namun, penurunan nilai derajat putih tidak ditemukan kecenderungan yang linier dengan peningkatan rasio ikan pada tekwan kering. Rasio 1,5:1 memiliki derajat putih paling rendah. Hal ini diduga kadar air yang tinggi pada rasio 1,5:1 dibandingkan rasio lain memengaruhi perubahan warna selama pengeringan. Pada proses pengeringan pada periode penurunan pertama (Gambar 2) ditemukan penurunan yang tidak signifikan antar perlakuan rasio ikan sehingga pada periode ini diduga terdapat air 
yang cukup untuk menjadi mediasi reaksi Maillard. Zhou et al. (2013) menyatakan bahwa air selama proses evaporasi dapat menjadi media terbentuknya ikatan disulfide dari gugus thiol protein di dalam reksi Maillard.

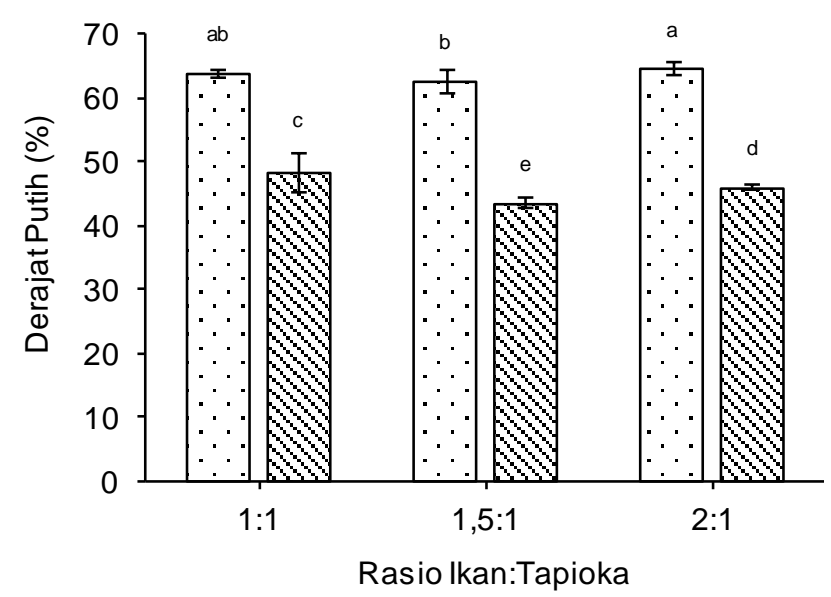

Keterangan: Notasi huruf yang berbeda menunjukkan perbedaan nyata antar perlakuan $(P \leq 0,05)$

Gambar 4. Derajat putih tekwan segar ( $\square$ ) dan tekwan kering $(\mathbb{S})$ dengan rasio ikan: tapioka berbeda $(1: 1,1,5: 1$, dan $2: 1)$

\section{Mikrostruktur}

Pengujian SEM dilakukan untuk melihat perubahan struktural tekwan akibat perngaruh rasio perbandingan ikan:tapioka dan perlakuan pengeringan. Foto mikrograf pengujian SEM ditampilkan pada Gambar 5 a-c. Foto SEM menunjukkan sampel kontrol dengan rasio 1,5:1 (b:b) dan 2:1 (b:b) membentuk struktur yang kompak antara protein ikan dan tapioka. Agregat karbohidrat terlihat lebih banyak terdapat pada sampel tekwan dengan rasio 1,5:1 (b:b) sementara filamen protein ikan ditemukan lebih banyak pada tekwan dengan rasio 2:1 (b:b). Pati tapioka pada tekwan setiap rasio telah tergelatinisasi sempurna disebabkan tahap persiapan sampel tekwan dilakukan diatas suhu gelatinisasi tapioka $\left(\sim 63^{\circ} \mathrm{C}\right)$.

Berbeda dengan kontrol, Gambar 5 c dan d menunjukkan terjadi perbedaan pengaruh pengeringan terhadap tekwan kering dengan rasio ikan:tapioka yang berbeda. Struktur yang berpori dengan ukuran yang besar dan jumlah banyak terlihat pada sampel tekwan kering dengan rasio 1,5:1 (b:b) sedangkan tekwan dengan rasio 2:1 (b:b) memiliki struktur yang lebih kompak. Hal ini menunjukkan bahwa rasio 2:1 memiliki resistensi kerusakan struktur yang lebih tinggi akibat perlakuan pengeringan dibandingkan dengan rasio 1,5:1. Dewi et al. (2011) menyatakan pengeringan dengan metode konvektif udara panas memicu terjadinya disrupsi protein ikan sehingga menurunkan solubilitas protein ikan yang selanjut- nya mengakibatkan pembentukan struktur yang kompak.

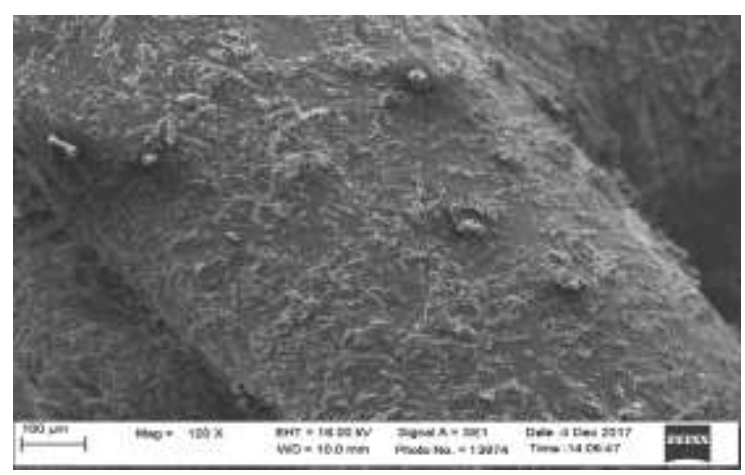

A

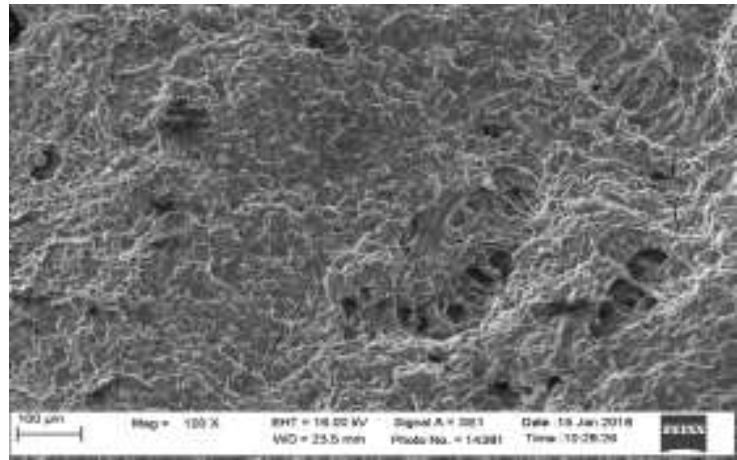

B

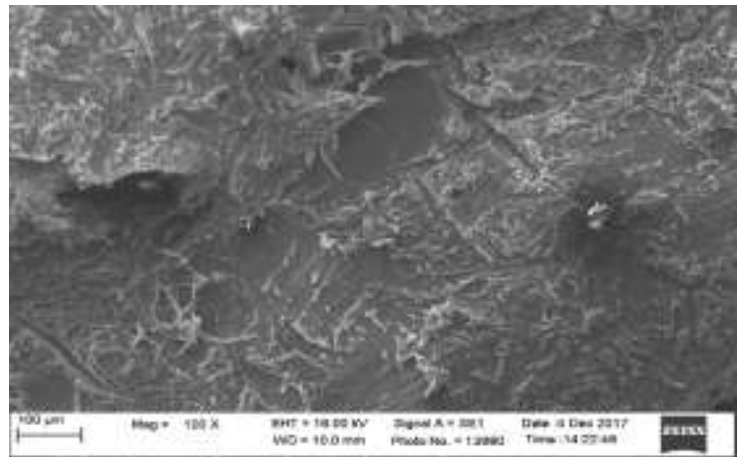

C

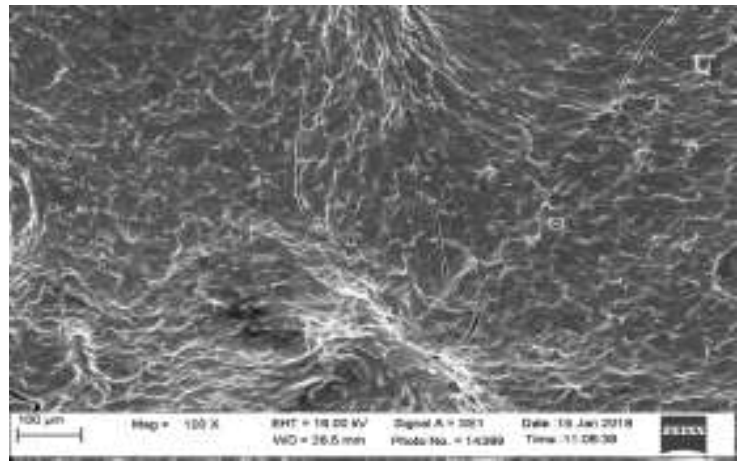

D

Gambar 5. Mikrostruktur tekwan (ikan:tapioka) kontrol tanpa pengeringan rasio 1,5:1 (A) dan rasio $2: 1(\mathrm{C})$, serta tekwan kering rasio 1,5:1 (B) dan 2:1 (D) 


\section{KESIMPULAN}

Secara keseluruhan, pengolahan tekwan kering dengan proses pengeringan konvektif menghasilkan karakteristik mutu fisik yang baik. Ukuran potong memengaruhi resistensi ekternal sementara rasio ikan memengaruhi resistensi internal evaporasi uap air selama pengeringan. Rasio ikan dan tapioka 2:1 dan ukuran potong $2 \mathrm{~cm}$ merupakan perlakuan terpilih dalam pembuatan tekwan kering. Foto mikrograf SEM menujukkan rasio $2: 1$ memiliki kerusakan struktur yang lebih rendah dibandingkan dengan rasio 1,5:1. Diperlukan kajian yang lebih mendalam dalam meningkatkan mutu fisik tekwan kering, seperti penambahan dryoprotectant dan hidrokoloid yang dapat mempertahankan mengurangi kerusakan fisik selama pengeringan dan meningkatkan karakterisitk rehidrasi tekwan kering.

\section{DAFTAR PUSTAKA}

[AOAC] Association of Official Analytical Chemists. 2012. Official Method of Analysis of the Association of Official Analytical of Chemists. Association of Official Analytical Chemists, Washington DC.

Agustini TW, Darmanto YS, Susanto E. 2009. Physicochemical properties of some dried fish products in indonesia. J Coastal Dev 12: 73-80.

Aprajeeta J, Gopirajah R, Anandharamakrishnan C. 2015. Shrinkage and porosity effects on heat and mass transfer during potato drying. J Food Eng 144: 119-128. DOI: 10.1016/j.jfoodeng. 2014.08.004.

Arrieche LS, Corrêa RG, Sartori DJM. 2009. Drying stresses and strains in a spherical food model. Comput Chem Eng 33: 1805-1813. DOI: 10.101 6/j.compchemeng.2009.05.013.

Arimi JM, Duggan E, O'Sullivan M, Lyng JG, O'Riordan ED. 2010. Effect of moisture content and water mobility on microwave expansion of imitation cheese. Food Chem 121: 509-516. DOI: 10.1016/j.foodchem.2010.01.001.

Brasiello A, Adiletta G, Russo P, Crescitelli S, Albanese D, Di Matteo M. 2013. Mathematical modeling of eggplant drying: Shrinkage effect. J Food Eng 114: 99-105. DOI: 10.1016/j.jfood eng.2012.07.031.

Breuninger WF, Piyachomkwan K, Sriroth K. 2009. Chapter 12 - Tapioca/Cassava Starch: Production and Use. 541-568. Elsevier Inc, New York, USA. DOI: 10.1016/B978-0-12-7462752.00012-4.
Carrin ME, Crapiste GH. 2009. Convective drying of foods. 123-151. CRC Press, Boca Raton, Florida.

Cunningham SE, Mcminn WAM, Magee TRA, Richardson PS. 2008. Experimental study of rehydration kinetics of potato cylinders. Food Bioprod Process 86: 15-24. DOI: 10.1016/j.fbp. 2007.10.008.

Danar R, Dasir. 2017. Studi berbagai jenis bahan pengembang terhadap reabsorpsi tekwan kering ikan gabus. EDIBLE 6: 36-45.

Deng Y, Luo Y, Wang Y, Yue J, Liu Z, Zhong Y, Zhao Y, Yang H. 2014. Drying-induced protein and microstructure damages of squid fillets affected moisture distribution and rehydration ability during rehydration. J Food Eng 123: 2331. DOI: 10.1016/j.jfoodeng.2013.09.006.

Dewi RS, Huda N, Ahmad R. 2011. Changes in the physicochemical properties, microstructure and sensory characteristics of shark dendeng using different drying methods. Am J Food Technol 6: 149-157. DOI: 10.3923/ajft.2011.149.157.

Djendoubi N, Boudhrioua N, Bonazzi C, Kechaou N. 2009. Drying of sardine muscles: Experimental and mathematical investigations. Food Bioprod Process 87: 115-123. DOI: 10.1016/j.fbp.2008. 07.003.

Erbay Z, Icier F. 2010. A review of thin layer drying of foods: Theory, modeling, and experimental results. Crit Rev Food Sci Nutr 50: 441-464. DOI: $10.1080 / 10408390802437063$.

Fudholi A, Sopian K, Ruslan MH, Alghoul MA, Sulaiman MY. 2010. Review of solar dryers for agricultural and marine products. Renew Sustain Energy Rev 14: 1-30. DOI: 10.1016/j.rser.2009. 07.032 .

Gulati T, Datta AK. 2015. Mechanistic understanding of case-hardening and texture development during drying of food materials. J Food Eng 166: 119-138. DOI: 10.1016/j.jfoodeng.2015.05. 031.

Gupta S, Cox S, Abu-Ghannam N. 2011. Effect of different drying temperatures on the moisture and phytochemical constituents of edible Irish brown seaweed. LWT-Food Sci Technol 44: 1266-1272. DOI: 10.1016/j.Iwt.2010.12.022.

Huda N, Li Leng A, Xan Yee C. 2010. Chemical composition, colour and linear expansion properties of Malaysian commercial fish cracker (keropok). As J Food Ag-Ind 3: 473-482.

Joardder MUH, Karim A, Kumar C, Brown RJ. 2016. Porosity: Establing the Relationship between Drying Parameters and Dried Food Quality. 2546. Springer, Madison, Amerika Serikat. 
Karneta R, Rejo A, Priyanto G, Pambayun R. 2013. Difusivitas panas dan umur simpan pempek lenjer. J Keteknikan Pertanian 27: 131-141. DOI: 10.19028/jtep.01.1.131-141.

Komolafe CA, Ogunleye IO, Adejumo AOD. 2011. Design and fabrication of a convective fish dryer. Pacific J Sci Technol 12: 89-97.

Lee CM, Patel KM. 1984. Analysis of juiciness of commercial frankfurters. J Texture Stud 15: 6773. DOI: 10.1111/j.1745-4603.1984.tb00368.x.

Mayor L, Sereno AM. 2004. Modelling shrinkage during convective drying of food materials - a review. J Food Eng 61: 373-386. DOI: 10.1016/ S0260-8774(03)00144-4.

Mustapha MK, Ajibola TB, Salako AF, Ademola SK. 2014. Solar drying and organoleptic characteristics of two tropical African fish species using improved low-cost solar driers. Food Sci Nutr 2: 244-250. DOI: 10.1002/fsn3.101.

Maldonado S, Arnau E, Bertuzzi MA. 2010. Effect of temperature and pretreatment on water diffusion during rehydration of dehydrated mangoes. J Food Eng 96: 333-341. DOI: 10.1016/j.jfood eng.2009.08.017.

Nurnadia AA, Azrina A, Amin I. 2011. Proximate composition and energetic value of selected marine fish and shellfish from the West Coast of Peninsular Malaysia. Int Food Res J 18: 137148.

Oliveira SM, Brandão TRS, Silva CLM. 2016. Influence of drying processes and pretreatments on nutritional and bioactive characteristics of dried vegetables - a review. Food Eng Rev 8: 134163. DOI: $10.1007 / \mathrm{s} 12393-015-9124-0$.

Ramadhan W, Santoso J, Trilaksani W. 2014. Pengaruh defatting, frekuensi pencucian dan jenis dryoprotectant terhadap mutu tepung surimi ikan lele kering beku. J Teknol Industri Pangan 25: 47-56. DOI: 10.6066/jtip.2014.25.1.47.

Ramírez JA, Uresti RM, Velazquez G, Vazquez M, Vázquez M, Vazquez M. 2011. Food hydrocolloids as additives to improve the mechanical and functional properties of fish products - a review. Food Hydrocolloid 25: 1842-1852. DOI: 10.1016/j.foodhyd.2011.05.009.

Ruiz-López II, Ruiz-Espinosa H, Luna-Guevara ML, García-Alvarado MA. 2011. Modeling and simulation of heat and mass transfer during drying of solids with hemispherical shell geometry. Comput Chem Eng 35: 191-199. DOI: 10.1016/j. compchemeng.2010.05.007.
Seiiedlou S, Ghasemzadeh HR, Hamdami N, Talati F, Moghaddam M. 2010. Convective drying of apple: Mathematical modeling and determination of some quality parameters. Int $\mathrm{J}$ Agric Biol 12: 171-178.

Sikes AL, Tobin AB, Tume RK. 2009. Use of high pressure to reduce cook loss and improve texture of low-salt beef sausage batters. Innov Food Sci Emerg 10: 405-412. DOI: 10.1016/j. ifset.2009.02.007.

Sun F, Huang Q, Hu T, Xiong S, Zhao S. 2014. Effects and mechanism of modified starches on the gel properties of myofibrillar protein from grass carp. Int J Biol Macromol 64: 17-24. DOI: 10.1016/j.ijbiomac.2013.11.019.

Tripathy PP, Kumar S. 2009. Influence of sample geometry and rehydration temperature on quality attributes of potato dried under open sun and mixed-mode solar drying. Int $\mathrm{J}$ Green Energy 6: 143-156. DOI: $10.1080 / 154350709027848$ 63.

Vega-Gálvez A, Andrés A, Gonzalez E, Notte-Cuello E, Chacana M, Lemus-Mondaca R. 2009. Mathematical modelling on the drying process of yellow squat lobster (Cervimunida jhoni) fishery waste for animal feed. Anim Feed Sci Technol 151: 268-279. DOI: 10.1016/j.anifeedsci.2009.0 1.003.

Wang Y, Zhang M, Mujumdar AS. 2011. Convective drying kinetics and physical properties of silver carp (Hypophthalmichthys molitrix) fillets. J Aquat Food Prod T 20: 361-378. DOI: 10.1080/ 10498850.2011 .575536$.

Wang Y, Zhang M, Mujumdar AS, Mothibe KJ. 2013. Quality changes of dehydrated restructured fish product from silver carp (Hypophthalmichthys molitrix) as affected by drying methods. Food Bioprocess Tech 6: 1664-1680. DOI: 10.1007/s 11947-012-0812-y.

Yadollahinia A, Jahangiri M. 2009. Shrinkage of potato slice during drying. J Food Eng 94: 52-58. DOI: 10.1016/j.jfoodeng.2009.02.028.

Zhang F, Fang L, Wang C, Shi L, Chang T, Yang H, Cui M. 2013. Effects of starches on the textural, rheological, and color properties of surimi-beef gels with microbial tranglutaminase. Meat Sci 93: 533-537. DOI: 10.1016/j.meatsci.2012.11. 013.

Zhou P, Guo M, Liu D, Liu X, Labuza TP. 2013. Maillard-Reaction-Induced modification and aggregation of proteins and hardening of texture in protein bar model systems. J Food Sci 78: 437-444. DOI: 10.1111/1750-3841.12061. 